\title{
Can We Predict Abdominal Aortic Aneurysm (AAA) Progression and Rupture by Non-Invasive Imaging?-A Systematic Review
}

\author{
Abeera Abbas, Rizwan Attia, Alberto Smith, Matthew Waltham* \\ King's College London British Heart Foundation Centre of Research Excellence, Academic Department of Surgery, Cardiovascular \\ Division, NIHR Biomedical Research Centre at Guy's and St Thomas' NHS Foundation Trust and King's College Hospital, London, \\ UK. \\ Email: *matthew.waltham@kcl.ac.uk
}

Received June 22 ${ }^{\text {nd }}, 2011$; revised August $8^{\text {th }}, 2011$; accepted August $20^{\text {th }}, 2011$.

\begin{abstract}
Introduction: The most commonly used predictor of aneurysm behavior in clinical decision-making is size. There are however small aneurysms that rupture and certain large aneurysms remain asymptomatic. There is growing evidence to suggest that other variables may provide better information on metabolic and physiological properties of aortic wall and therefore better predict aneurysm behavior. Methods: The literature was systematically reviewed from 1975-May 2011 to examine the evidence to support the use of non-invasive imaging modalities that might predict aneurysm behavior. Results: Ultrasound can be used to measure multiple dynamic aortic properties (i.e. distensibility and compliance) in addition to diameter. These parameters better predict aneurysm behavior. Computer tomography can utilize assessment of aortic calcification, presence of intra-luminal thrombus and distensibility. Finite element analysis model has been validated in-vivo to calculate peak wall stress, assess effects of intra-luminal thrombus and calcification. It however relies on assumptions related to aneurysm properties and therefore remains relatively inaccurate in the clinical setting. Small numbers of observational human studies have evaluated the role of ${ }^{18} F-F D G ~ P E T / C T$ in aneurysms. Larger studies are needed, as ${ }^{18}$ F-FDG uptake is patchy and heterogeneous even in small number of patients. It varies in the same patient with time, as aneurysms grow intermittently. We discuss functional magnetic resonance imaging with novel tracers such as 99 mTc-annexin-V and nanoparticles. Conclusion: Multimodality imaging with complementary methods such as CT, functional MRI (fMRI), ultrasound and physiological measurements improve the definition of aneurysm pathobiology. Larger-scale clinical validation is beginning to promise a new paradigm in cardiovascular diagnostics.
\end{abstract}

Keywords: Abdominal Aortic Aneurysm (AAA), Progression and Rupture, Non-Invasive Imaging

\section{Introduction}

Abdominal aortic aneurysm (AAA) rupture is associated with a high morbidity and $80 \%-90 \%$ mortality. Currently the aortic diameter is the only feature that is used to predict the risk of rupture. The other recognized risk factors for continued expansion of the aneurysm include smoking, female gender and higher mean blood pressure. More recently developments in imaging have allowed other features of the AAA to be proposed as predictors of rupture risk; these include arterial wall stiffness, intraluminal thrombus (ILT), wall tension and peak wall stress [1].
Two randomized control trials (RCTs), the United Kingdom Small Aneurysm Trial (UKSAT) and the Aneurysm Detection and Management (ADAM) study, have shown that patients with small AAA can safely be kept on surveillance programmes [2,3]. There is still, however, much debate whether surveillance is appropriate for all patients with small AAA as some of these patients may be at increased risk of rupture [4]. In the Multicentre Aneurysm Screening Study (MASS Trial) 5\% of the patients undergoing ultrasound surveillance died from aneurysm related causes; either after rupture or symptom onset that led to urgent surgery [5]. Autopsy studies have demonstrated $10 \%-24 \%$ of all ruptured AAA have a 
diameter of less than $5.5 \mathrm{~cm}[6,7]$. Furthermore, the UKSAT trial showed that more than $60 \%$ of patients with small aneurysms required surgery within six years [2]. This is predominantly for reaching size criteria but also for symptom onset. This has led some to argue that it may be safer to operate on some patients with small AAA. This is more the case now with the widespread application of endovascular stent repair, with potentially lower procedural risks. Two randomized control trials, Comparison of surveillance vs. Aortic Endografting for Small Aneurysm Repair [8] (CAESAR) and Positive Impact of endovascular Options for Treating Aneurysm early [9] (PIVOTAL) have failed to show any survival benefit of an early EVAR versus surveillance of subjects with small AAA. Although these trials failed to demonstrate an overall benefit as a group, there is a clinical advantage in selecting patients at higher risk of early rupture at a small size to be treated.

Diameter, pulse wave velocity (PWV), arterial stiffness, elasticity, peak wall stress (PWS), compliance, distensibility and pressure-strain modulus (Ep) describe a range of properties of the aortic wall that have been described to predict aneurysm expansion or rupture (Table 1). Identification of an individual's aneurysm progression and rupture risk by non invasive imaging could allow selection of patients with small AAA for early repair. This review analyzes non-invasive techniques that may be useful in predicting the aneurysm expansion or rupture.

\section{Methods}

\subsection{Review Criteria}

A search of Medline using the OVID interface and other non-indexed citations was performed from 1975-May 2011. The search strategy provided 91050 articles of which 37 were reviewed in full and form the basis of this review. The detailed review methodology is outlined below in the Methods section.

\subsection{Data Collection, Limitations and Analysis}

Systematic literature review was conducted using the OVID interface for PubMed database (1975 - May 2011). The key words used for search in PubMed were "abdominal aortic aneurysm" (\$, mp), OR "imaging predicting AAA expansion OR rupture" (\$, mp), AND "compliance" (\$, mp), OR "distensibility" (\$, mp), OR "pulse wave velocity" (\$, mp), OR "peak wall stress" $(\$, \mathrm{mp})$ OR "PET/CT" (\$, mp) OR MRI (\$, mp). A manual search of relevant publications was also done to identify noninvasive imaging modalities for aorta or AAA (Table 4). There were no language restrictions. Having used the above strategy to identify potentially relevant abstracts, papers were independently reviewed by two authors (AA and RA), to assess their suitability for data extraction according to formally laid out criteria. Differences in opinion were settled by consensus with a fourth author (MW). Data were extracted and stored in a proforma.

Table 1. Physical characteristics of arterial wall and measurement technique.

\begin{tabular}{|c|c|c|}
\hline Physical characteristics & Definitions & Measurement technique \\
\hline Pulse wave velocity (PWV) & $\begin{array}{l}\text { The velocity of the pressure wave to travel over a specific distance between } \\
\text { two sites }[10,11] \\
\text { PWV }=\Delta x / \Delta t \\
\Delta x, \text { the distance between two recording sites } \\
\Delta t, \text { the transit time between the arrival of pressure wave at sites }\end{array}$ & $\begin{array}{l}\text { Applanation tonometry [10,12], } \\
\text { Phase Contrast MRI [13]. }\end{array}$ \\
\hline Compliance (C) & $\begin{array}{l}\text { It is the fractional change in vessel cross sectional area divided by the change } \\
\text { in distending pressure [14]. } \\
\mathrm{C}=\Delta A / \Delta p \\
\text { or } \\
\mathrm{C}=1 /(\mathrm{PWV})^{2} \rho \\
\rho=1055.103\left[\mathrm{~kg} / \mathrm{m}^{3}\right] \text { denotes the mass density of blood that is assumed to be } \\
\text { constant. }\end{array}$ & $\begin{array}{l}\text { Indirectly by PWV. } \\
\text { Directly from ECG gated Phase } \\
\text { Contrast MRI [15], Tissue } \\
\text { Doppler imaging (TDI) [14]. }\end{array}$ \\
\hline Distensibility (D) & $\begin{array}{l}\text { It is defined as the relative change in vessel cross-sectional area }(\mathrm{A}) \text { that } \\
\text { occurs during the cardiac cycle, divided by the corresponding change in } \\
\text { blood pressure }(\Delta p)[16] . \\
\mathrm{D}=\Delta A / A_{o} \cdot \Delta p \\
A_{o} \text { is minimum vessel area and } \Delta \mathrm{A} \text { difference in max and min area }\end{array}$ & $\begin{array}{l}\text { ECG gated CT }[16,17] \text { and MRI } \\
{[15,18], \text { Diamove }[19,20]}\end{array}$ \\
\hline Pressure strain modulus $\left(E_{p}\right)$ & $\begin{array}{l}E_{p} \text { is a measure of the stiffness }(\beta) \text { or lack of elasticity of an artery [20]. } \\
\qquad E_{p}=\left(P_{\mathrm{s}}-P_{d}\right)\left[D_{d} /\left(D_{s}-D_{d}\right)\right] \\
\text { Arterial blood pressures at peak systole }\left(P_{\mathrm{s}}\right) \text { and end diastole }\left(P_{d}\right) \text { and the } \\
\text { corresponding arterial diameters }\left(D_{s} \text { and } D_{d}\right)\end{array}$ & $\begin{array}{l}\text { ECG gated CT }[16] \text { and } \mathrm{MRI}^{17} \text {, } \\
\text { Diamove }[19,20]\end{array}$ \\
\hline Peak wall stress & $\begin{array}{l}\text { The maximal force per unit area within the AAA wall at systolic blood } \\
\text { pressure. }\end{array}$ & $\begin{array}{l}\text { FEA model using 3D CT images } \\
{[21-23] \text { and ABAQUS software }}\end{array}$ \\
\hline
\end{tabular}


The quality of the papers was assessed by the authors according to the criteria already laid out [24].

\subsection{Primary Outcome Measures}

The use of non-invasive imaging that predicted AAA expansion or rupture in humans, animal or computer models.

\subsection{Types of Studies}

Randomised control trails of any size or length allowing assessment for short, medium and long-term outcomes, inception cohort studies, individual cohort studies with $>80 \%$ follow-up were primarily used (Level $1 \mathrm{~A}-\mathrm{C}$ ). We also included retrospective cohort studies where there were untreated control groups in RCTs (Level 2A-B). Studies representing lower level of evidence as per Oxford Centre for Evidence-based Medicine (CEBM)-Levels of Evidence (March 2009) [25] were excluded.

\subsection{Types of Participants}

Adults patients ( $\geq 18$ years old) undergoing non-invasive imaging for AAA screening, diagnosis, planning treatment, follow-up were included. No restrictions were placed on patient case mix or severity of disease pathology. This potentially allows for stratification of effects by level of patient risk of rupture.

\section{Results}

\subsection{Description of Studies}

The studies that looked at parameters (Table 1), which may predict AAA expansion or rupture, were included. In addition, non-invasive imaging modalities that may predict aneurysm growth by detecting metabolic activity within aneurysm wall were also included (PET/CT, functional MRI). The studies that predicted aneurysm sac expansion post EVAR were excluded.

\subsection{Results of Search}

We identified 91050 references by our search criteria (Figure 1). From these 104 studies were thought to be of relevance and the full papers were sought. Of these 37 studies met the inclusion criteria. Imaging modalities represented were, ultrasound, CT, PET/CT, finite element analysis and MRI. The parameters used to predict AAA outcome in literature were reviewed (Tables 2 and 3): 5 pulse wave velocity, 1 vibrometry, 5 distensibility, 5 compliance, 13 peak wall stress, 7 FDG-PET/CT and 1

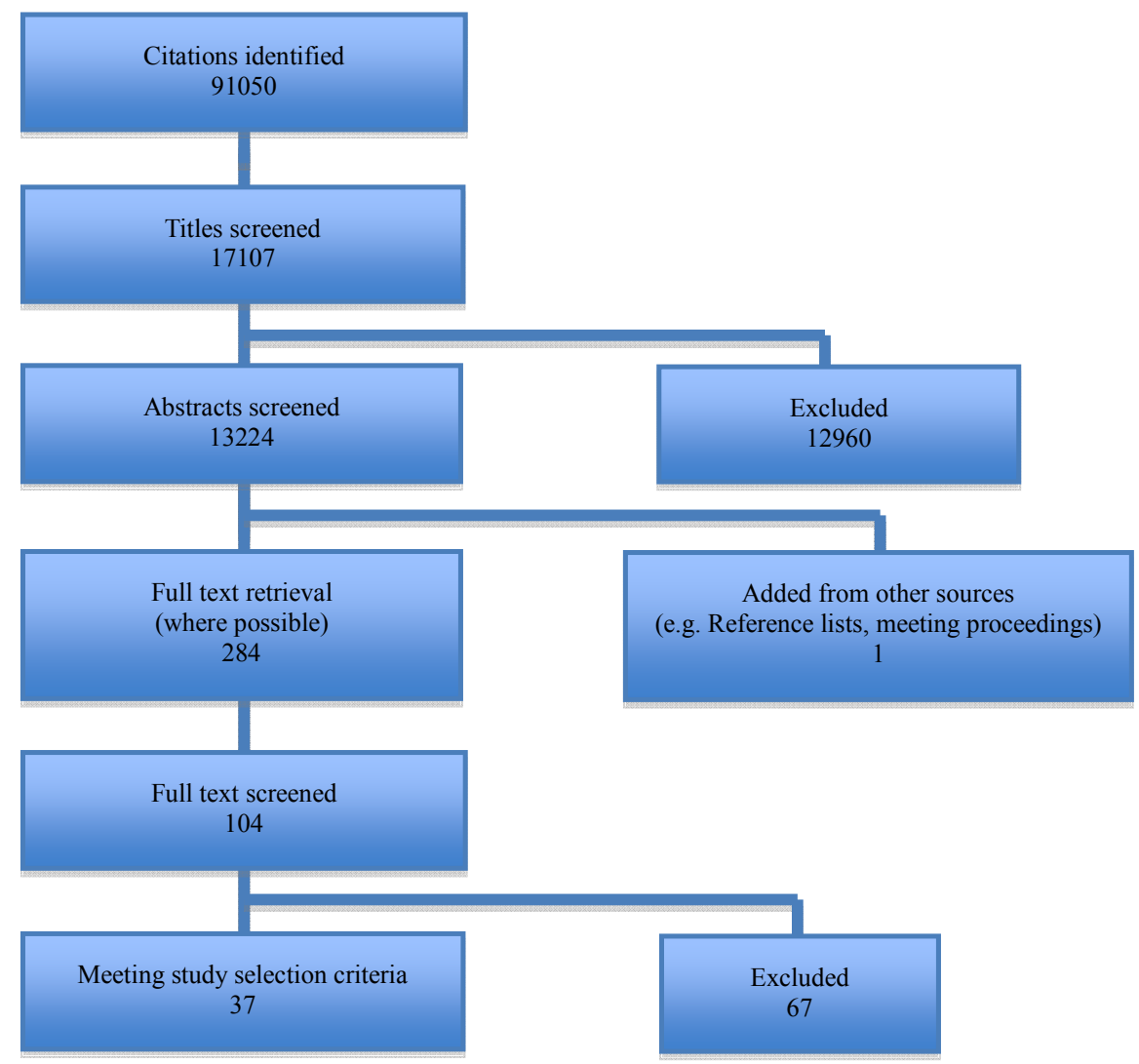

Figure 1. Flow diagram. 
novel particles.

\subsection{Limitation of Bias}

General bias is bound to exist in terms of reporting positive data in the literature however it is difficult to account for this. The inclusion of retrospective studies entails bias inherent in terms of study design. Inclusion of studies using small number of patients with novel imaging modalities may not be generalisable to all patients with aneurysms. However due to the costs involved and the novel experimental nature of the application of these techniques we felt it appropriate to include the studies into representing the investigation and management of patients with AAA. Although currently small scale they may present important lines for investigative development in the future. They may therefore form the basis of future RCTs.

\section{Ultrasound}

Currently the best determinant of the risk of AAA rupture is the maximum diameter [26]. Ultrasound has been used since the early 1960s to measure AAA diameter and it has a sensitivity approaching $100 \%$ to detect AAA [27]. Although ultrasound is operator dependent the measurements are reproducible. It is non-invasive, easily available, cost effective and modern portable scanners allow community based screening and surveillance. Recent advances include devices that automatically detect the aortic diameter with a $90 \%$ sensitivity without the need for a trained operator [28]. Ultrasound tends to measure AAA diameter slightly smaller than CT scan [29].

The UKSAT showed that patterns of expansion are highly variable. Certain patients having a uniform rate of aneurysm expansion, some aneurysms grow in intermittent bursts whereas certain aneurysms remaining stable. Traditionally expansion rates of greater than $1 \mathrm{~cm}$ per year or $0.5 \mathrm{~cm}$ per 6 months have been used as indicators of increased rupture risk but this is not borne out in data from the UKSAT study [30]. These criteria have therefore not been included as a reason to refer a patient with a small AAA for vascular specialist assessment in the National AAA Screening Programme (NAAASP).

Ultrasound has also been used to measure the compliance and distensibility of AAA. Compliance is a measure that reflects mechanical properties of the aortic wall and increases with AAA diameter [19] (Table 1). AAA expansion is the result of wall remodeling and this is reflected by changes in compliance. Tissue Doppler imaging (TDI) measures compliance by utilizing the Doppler effect to assess wall displacement at points along the aorta during the cardiac cycle. Compliance is calculated from the amount of displacement of the vessel wall and the measured blood pressure. Long et al demonstrated a correlation between compliance and aortic size using TDI. There was significant positive linear relationship between maximum diameter and segmental compliance but not with the pressure strain modulus or stiffness [14]. Further studies are now required to assess whether compliance measured during routine AAA ultrasound monitoring using TDI could be a predictor of expansion.

Distensibility is expressed as the pressure-strain modulus $\left(E_{p}\right)$ which is a measure of the stiffness $(\beta)$ or lack of elasticity of an artery [31] (Table 1). If $E_{p}$ and $\beta$ are higher then the artery is less distensible and has lower arterial wall compliance [19]. These characteristics differ from compliance in that they are measures of the amount of change in diameter with pressure change, whereas compliance reflects the rate of that change. Aortic distensibility decreases with age and can be measured noninvasively by either an ultrasound scan-based echo tracking technique (Diamove) [19], ECG-gated CT [16] or MRI [18]. All of these use an estimated central blood pressure value from sphygmomanometer to calculate compliance; this may be inaccurate in certain cases. The Diamove $[19,20]$ device utilizes a 3.5-MHz B-mode ultrasound probe to produce an image of the aorta or aneurysm. The anterior and posterior walls are then tracked and the change of vessel diameter during each cardiac cycle is measured. The acquired data is analyzed to calculate the distensibility. Diamove can also measure diameter and compliance with acceptable reproducibility (Table 2) [32]. A prospective multi-centre study showed that a reduction in distensibility over time (increase in $E_{p}$ ) significantly reduced the time to rupture independently of aneurysm diameter [20]. Baseline aortic wall distensibility may provide an additional parameter for AAA to optimize the indication and time for elective repair [33].

Vibrometry is a novel use of ultrasound to estimate wall stress in rubber tube models of aneurysm sac and may have potential to predict the risk of rupture in AAA [34]. Ultrasound can also be used to map the propagation of pulse wave along the aneurysm wall and this has been described as a tool that may predict AAA rupture [11]. Wall stress and PWV are discussed in detail on sections on CT and MRI respectively.

The above evidence suggests that ultrasound can be used to measure multiple dynamic properties of the aortic wall in addition to its diameter. These parameters may make US a better tool to predict AAA expansion or rupture.

\section{Computed Tomography (CT)}

CT scan can accurately diagnose abdominal aortic aneurysms and is mostly commonly used for assessment of 
Table 2. Summary of relevant published series on compliance, aortic pulse wave velocity and distensibility in AAA disease.

\begin{tabular}{|c|c|c|c|c|c|}
\hline $\begin{array}{l}\text { Parameter } \\
\text { studied }\end{array}$ & $\begin{array}{l}\text { Author, year, } \\
\text { country }\end{array}$ & Imaging modality & $\begin{array}{l}\text { Number of } \\
\text { subjects/model }\end{array}$ & Aneurysms & Summary of findings \\
\hline Compliance & $\begin{array}{l}\text { Wilson K et al. } \\
(1998, \mathrm{UK})[19]\end{array}$ & Diamove & 112 patients & AAA & $\begin{array}{l}\text { - Seven ruptures and } 16 \text { elective repairs } \\
\text { - Baseline compliance was significantly related } \\
\text { to rupture }\end{array}$ \\
\hline Compliance & $\begin{array}{l}\text { Wilson K et al. } \\
(1999, \mathrm{UK})[35]\end{array}$ & $\begin{array}{l}\text { Diamove, an ultrasonic } \\
\text { echo-tracking device was } \\
\text { used to measure } \\
\text { elastic-strain modulus } \\
\text { (Ep) and stiffness }(\beta)\end{array}$ & 60 patients & & $\begin{array}{l}\text { - Large aneurysms were less compliant. } \\
\text { - Compliance and growth rate were not related. }\end{array}$ \\
\hline Compliance & $\begin{array}{l}\text { Long A et al. } \\
\qquad(2004, \\
\text { France })[36]\end{array}$ & Tissue Doppler imaging & 35 patients & $\begin{array}{c}\text { AAA } \\
(\text { mean size } 39 \mathrm{~mm})\end{array}$ & $\begin{array}{l}\text { - Eight compliance parameters studied. } \\
\text { - Relation between compliance and AAA } \\
\text { expansion/rupture } \mathrm{r}=0.54 ; \mathrm{p}=0.001 \text {. }\end{array}$ \\
\hline $\begin{array}{l}\mathrm{PWV} / \text { Thoracic } \\
\text { aortic } \\
\text { Compliance }\end{array}$ & $\begin{array}{l}\text { Russo L (2006, } \\
\text { Italy) [37] }\end{array}$ & $\begin{array}{l}\text { Doppler echocardiography } \\
\text { PWV was determined at } \\
\text { two points in descending } \\
\text { thoracic aorta }\end{array}$ & 43 patients & AAA (infra-renal) & $\begin{array}{l}\text { - Postoperatively PWV was measured in } \\
\text { ruptured group (26) and elective group (17). } \\
\text { - A striking increase in thoracic aortic } \\
\text { compliance was observed in patients with } \\
\text { ruptured AAA (p-value }=0.05 \text { ). }\end{array}$ \\
\hline PWV & $\begin{array}{l}\text { Fujikura K (2007, } \\
\text { USA) [38] }\end{array}$ & Ultrasound (ECG gated) & Mouse model & $\begin{array}{l}\mathrm{CaCl}_{2} \text { treated } \\
\text { aortas }\end{array}$ & $\begin{array}{l}\text { - AAA was induced using } \mathrm{CaC} 12 \\
\text { - No regional difference in PWV of normal and } \\
\mathrm{CaCl} 2 \text { treated aortas }\end{array}$ \\
\hline PWV & $\begin{array}{l}\text { Luo J et al. }(2008 \text {, } \\
\text { USA) [39] }\end{array}$ & Ultrasound (ECG gated) & 6 patients & 5-AA \& 1-AAA & $\begin{array}{l}\text { - Pulse wave imaging technique } \\
\text { - Subjects with normal aorta were young and } \\
\text { subject with was } 70 \text {. } \\
\text { - PWV was higher in AAA subject. } \\
\text { - Wall velocities are significantly lower in } \\
\text { AAA subject. }\end{array}$ \\
\hline PWV & $\begin{array}{l}\text { Luo et al. }(2009 \text {, } \\
\text { USA) [40] }\end{array}$ & Ultrasound (ECG gated) & $\begin{array}{l}\text { Mouse model } \\
\qquad(30)\end{array}$ & $\begin{array}{l}\text { AngII treated } \\
\quad \text { aortas }\end{array}$ & $\begin{array}{l}\text { - } \text { PWV in sham aortas is relatively uniform. } \\
\text { PWV in aneurysmal region of the } \\
\text { AngII-treated aortas are lower than in the } \\
\text { proximal region }(\mathrm{P}<0.005) \text {. } \\
\text { - } \text { PWV in the AngII-treated aortas is lower than } \\
\text { sham aortas }((\mathrm{P}<0.005) \text {. }\end{array}$ \\
\hline PWV & $\begin{array}{l}\text { Parasekevas }(2009, \\
\text { Greece) [41] }\end{array}$ & $\begin{array}{l}\text { cfPWV (oscillometric } \\
\text { device) }\end{array}$ & 24 patients & AAA & $\begin{array}{l}\text { - Post op PWV measurements higher than pre } \\
\text { op }(\mathrm{P}<0.0001)\end{array}$ \\
\hline Vibrometry & $\begin{array}{l}\text { Agarwal }(2006, \\
\text { UK) }[34]\end{array}$ & Ultrasound/Doppler & $\begin{array}{l}\text { Porcine and } \\
\text { rubber model }\end{array}$ & Aorta & $\begin{array}{l}\text { - Changes in wall tension can be measured } \\
\text { directly. } \\
\text { - This method may detect rupture risk in native } \\
\text { aneurysms and endotension after EVAR. }\end{array}$ \\
\hline Distensibility & $\begin{array}{l}\text { Makita s et al. } \\
(2000, \text { Japan })[42]\end{array}$ & $\begin{array}{l}\text { Distensibility measured in } \\
\text { carotid arteries using US }\end{array}$ & 102 patients & $\begin{array}{l}\text { AAA (mean size } \\
52.3 \mathrm{~mm})\end{array}$ & $\begin{array}{l}\text { - Three groups but comparison within AAA } \\
\text { group showed reduced carotid distensibility } \\
\text { in ruptured cases }(\mathrm{P}<0.05) \\
\text { - Ruptured AAA }(\mathrm{n}=14) \text { and non-ruptured } \\
(\mathrm{n}=88)\end{array}$ \\
\hline
\end{tabular}




\begin{tabular}{|c|c|c|c|c|c|}
\hline Distensibility & $\begin{array}{l}\text { Wilson K (2001, } \\
\text { UK) [43] }\end{array}$ & $\begin{array}{c}\text { Diamove, Serum elastin } \\
\text { peptides (SEP), plasma } \\
\text { elastin- } \alpha_{1} \text {-antitrypsin complex } \\
\text { (E-AT), procollagen } \\
\text { III-N-terminal propeptide } \\
\text { (PIIINP) were measured by } \\
\text { enzyme-linked immunoassay. }\end{array}$ & 62 patients & $\begin{array}{l}\text { AAA } \\
\text { median diameter } \\
42 \mathrm{~mm}\end{array}$ & $\begin{array}{l}\text { - AAA's of similar size have variable } \\
\text { distensibility. } \\
\text { - An increased elastolysis is associated with } \\
\text { increased AAA wall distensibility; whereas } \\
\text { increased collagen turn-over is associated } \\
\text { with reduced distensibility. }\end{array}$ \\
\hline Distensibility & $\begin{array}{c}\text { Wilson K } \\
(2003, \text { UK) [20] }\end{array}$ & Diamove & 210 patients & AAA & $\begin{array}{l}\text { - End points: rupture, surgery, death or end of } \\
\text { study period. } \\
\text { - In the Cox model, female gender, larger di- } \\
\text { ameter, higher diastolic BP, and a reduction } \\
\text { in distensibility (increase in Ep) over time } \\
\text { significantly reduced the time to rupture. } \\
\text { - The measurement of AAA distensibility, } \\
\text { diastolic BP, and diameter may provide a } \\
\text { more accurate assessment of rupture risk than } \\
\text { diameter alone. }\end{array}$ \\
\hline $\begin{array}{l}\text { Distensibility } \\
\text { and } \\
\text { compliance }\end{array}$ & $\begin{array}{l}\text { Van't Veer et al., } \\
(2008, N L)[15]\end{array}$ & MRI & 10 subjects & $\begin{array}{l}\text { AAA (mean } \\
\text { diameter } \\
5.8 \pm 0.6)\end{array}$ & $\begin{array}{l}\text { - MRI based monitoring of distensibility and } \\
\text { compliance may be useful for rupture risk as- } \\
\text { sessment. } \\
\text { - Secondary outcome was to compare } \\
\text { intra-aneurysmal pressure with brachial } \\
\text { cuff pressure measurements. } \\
\text { - Non-invasive blood pressure data } \\
\text { overestimates distensibility and compliance. }\end{array}$ \\
\hline Distensibility & $\begin{array}{l}\text { Ganten, (2008, } \\
\text { Ger) [17] }\end{array}$ & $\begin{array}{c}\text { Four detector-row CT } \\
\text { system using a modified } \\
\text { CT-angiography protocol. }\end{array}$ & 67 patients & $\begin{array}{l}\text { AAA Values were } \\
\text { compared for small } \\
<5 \mathrm{~cm}(\mathrm{n}=44) \text { and } \\
\text { large }>5 \mathrm{~cm}(\mathrm{n}= \\
23) \text { aneurysms. }\end{array}$ & $\begin{array}{l}\text { - Distensibility between smaller and larger } \\
\text { aneurysms was not found to be significant. } \\
\text { - The reduction of distensibility within } \\
\text { aneurysms compared to normal proximal } \\
\text { aorta is subtle; the lack of difference between } \\
\text { both small and large aneurysms suggests that } \\
\text { this reduction occurs early in the aneurysm's } \\
\text { development. } \\
\text { - In order to compare results with literature } \\
\text { values, distensibility was also converted } \\
\text { into pulse wave velocity PWV [m/s] } \\
\text { - Reduced distensibility might be a predictive } \\
\text { parameter in patients with high risk of aortic } \\
\text { disease. }\end{array}$ \\
\hline
\end{tabular}

anatomy prior to endovascular or open aneurysm repair. Supplementary data regarding proximal and distal aneurysm extension in relationship to branches, characteristics of intra-luminal thrombus, and aortic neck length, diameter and angulation can all be obtained by CT. In addition to anatomical details CT also provides information on aortic wall calcification. As discussed above CT can be used to measure distensibility [16] (Table 2). Distensibility is reduced within the aneurysmal segment compared to normal proximal aorta in both small and large AAA. It has been suggested that changes in distensibility might affect the risk of subsequent aneurysm formation [17].

Nearly $75 \%$ of all AAAs have varying degrees of ILT [44]. The role of ILT in predicting expansion or rupture is much debated. In one study it was found that aneurysm wall covered with thrombus is thinner and shows signs of inflammation and apoptosis of smooth muscle cells. These findings may be related to a reduced structural integrity and stability of the wall and an increased risk of rupture [45]. The presence of ILT in AAA may affect intra-aneurysmal pressure which may in-turn cause rupture. Schurink et al. showed that ILT does not reduce the mean blood pressure or the pulse pressure near the aneurysmal wall and therefore does not reduce aneurysm rupture risk [46] but Stenbaek et al. support that thrombus and its growth rate are associated with an increased risk of AAA rupture [47]. There is however no overwhelming evidence related to the consequences of ILT.

In summary, along with anatomical details of the aneurysm to decide on the best mode of treatment, CT can provide us with physiological variables such as distensibility and degree of calcification. These may allow better assessment of aneurysm risk of expansion and rupture. 
The role of ILT in aneurysm progression need further study.

\subsection{Finite Element Analysis}

Finite element analysis (FEA) techniques can be used to create a model of aneurysmal disease that gives a better evaluation of rupture risk of AAA [48]. Peak wall stress (PWS) can be calculated using these models rather than simply applying the Law of Laplace [49]. The CT data are mathematically processed to create a refined 3-D mesh, made up of 20,000 or more elements. The geometry of the aorta and aneurysm wall including tortuous anatomy and vessel bifurcations is taken into account.

Peak wall stress is the maximal force per unit area within the AAA wall at systolic blood pressure. It is calculated by using a mathematical model initially developed by Raghavan and Vorp, based on mechanical properties of freshly excised AAA specimens [50-52]. The model assumes the wall to be homogenous, incompressible and of constant thickness. The stress distribution in the AAA wall (von Mises stress) is calculated at given points and this gives a single value reflecting the full $3 \mathrm{D}$ stress field at each point in the model [50,51].

Computed peak wall stress using this model shows much higher PWS in the AAA $\left(29-45 \mathrm{~N} / \mathrm{cm}^{2}\right)$ compared with normal aorta $\left(12 \mathrm{~N} / \mathrm{cm}^{2}\right)$ [53]. In addition the failure strength of normal aortas was much greater $\left(121 \mathrm{~N} / \mathrm{cm}^{2}\right)$ than of a typical AAA wall $\left(65 \mathrm{~N} / \mathrm{cm}^{2}\right)$. The other factors such as diameter, axial length and volume can also be varied to determine their influence on PWS [51]. A number of studies (Table 3) have supported the predicttive ability of PWS to determine rupture risk in aneurysm is superior to diameter [21-23].

The effect of intra-luminal thrombus on the risk of rupture is discussed above but a recent study has also included intra-luminal thrombus in stress analysis, where it appeared to reduce stress [54]. The presence of calcification has also been included in the model and increases AAA wall stress $[55,56]$. The biomechanical stability of AAA is dependent more on the location of calcification than the relative amount of calcification. Xu et al. showed a potential link between high wall stress and accelerated metabolism in aortic aneurysm wall on PET/CT [57].

The point of maximum PWS in FEA modeling is referred to as the inflection and this is not usually at the maximum diameter of the aorta. This questions the theory that rupture simply occurs at the point of maximum mechanical stretch where the diameter is greatest [58]. Diameter was first used in 1966 to predict AAA at high risk of rupture and has since been modified in the light of experience and more accurate imaging [59]. The simple observation that not all AAAs rupture at a specific di- ameter indicates that other patient-specific and aneurysm-specific variables may have an effect, for example: obstructive lung disease, smoking, hypertension, a widened pulse pressure, the ratio of the aneurysm diameter to the diameter in the adjacent normal aorta, and aortic wall tension [58].

Presently, it is not possible to obtain exact peak wall stress or accurate local wall strength measurements. The FEA model, although claimed to be validated In vivo, still relies on a number of assumptions related to physical properties and therefore remains relatively in-accurate.

\subsection{Positron Emission Topography (PET/CT)}

PET offers the possibility of using radiotracers to image functional activity in the wall of the aorta (Table 4). Currently the only tracer with clinical application is the glucose analogue 18-fluorine (18F) flurodeoxyglucose (FDG). It enables detection of increased glucose metabolism. Increased uptake is characteristic of many cancers and other non-malignant processes such as infection and inflammation [68]. It could therefore potentially assess the metabolic activity in the aneurysmal wall [69]. FDG uptake is expressed as standardized uptake values (SUV), for tissue attenuation. The SUV is calculated either pixelwise or over a region of interest for each image.

Increase enzyme and cellular activity in the AAA wall are seen histologically at the site of rupture and these "hot spots" may be responsible for focal weakening and rupture at relatively low levels of intra-luminal pressure [70,71]. FDG-PET/CT is a promising technique that may identify such areas of activity and thus may be able to predict an increased risk of growth or rupture [72,73]. PET-CT imaging with 18-fluorine (18F)-labeled nanoparticles allows quantization of macrophage content in a mouse model of AAA [74].

In a pilot study of fifteen patients with AAA, the maximum aortic FDG uptake correlated significantly with histopathologic characteristics of aneurysm wall instability and the clinical presence of symptoms [75]. Patients had a FDG-PET/CT followed by open repair and biopsies were taken from increased FDG uptake areas to correlate with histology. There was a significant correlation of FDG signal intensity with tissue inflammation, increased macrophage and T cell accumulation and MMP-9 activity, an enzyme associated with aneurysm rupture [76]. Patients with AAA had a significantly increased uptake as compared to normal aortas [77]. Similarly significantly higher uptake is observed in inflammatory aneurysms compared to non-inflammatory aneurysms [78]. Furthermore, FDG uptake in aortic wall seems to increase with age and is not related to calcification [68].

The preliminary findings from an observational longi- 
Table 3. Studies reporting peak wall stress (PWS) as a predictor of aneurysm expansion and rupture.

\begin{tabular}{|c|c|c|c|c|}
\hline $\begin{array}{l}\text { Author, year, } \\
\text { country }\end{array}$ & Imaging modality & $\begin{array}{l}\text { Number of } \\
\text { patients }\end{array}$ & FEA model & Summary of findings \\
\hline $\begin{array}{l}\text { Fillinger et al. } \\
(2002, \text { USA) [21] }\end{array}$ & CT scan & 48 patients & $\begin{array}{c}\text { nonlinear hyperelastic } \\
\text { model }\end{array}$ & $\begin{array}{l}\text { - } 10 \text { ruptured, } 8 \text { symptomatic and } 30 \text { elective } \\
\text { - Purpose was to calculate PWS In vivo using 3D } \\
\text { computer modelling } \\
\text { - PWS was significantly higher in ruptured AAAs } \\
(\mathrm{p}=0.03)\end{array}$ \\
\hline $\begin{array}{l}\text { Fillinger et al. } \\
(2003, \text { USA) [22] }\end{array}$ & $\begin{array}{l}\text { Spiral CT scan and } \\
\text { 3-D reconstruction } \\
\text { for elective AAA } \\
\text { evaluation (not done } \\
\text { to measure PWS) }\end{array}$ & $\begin{array}{l}103 \text { patients and } \\
159 \text { CT scans }\end{array}$ & $\begin{array}{c}\text { nonlinear hyperelastic } \\
\text { model }\end{array}$ & $\begin{array}{l}\text { - Purpose was to analyze rupture risk over time in patients. } \\
\text { - Three groups: observation (no intervention for at least } \\
1 \text { year), elective repair(Elective repair within year), } \\
\text { emergent repair for rupture } \\
\text { - Peak wall stress appeared better to differentiate } \\
\text { patients who later required emergent repair (elective vs } \\
\text { emergent repair: diameter, } p=0.5 ; \text { stress, } p<0.0001 \text { ). } \\
\text { - Peak wall stress and gender were significant } \\
\text { independent predictors of rupture. }\end{array}$ \\
\hline $\begin{array}{l}\text { Venkatasubramaniam } \\
\text { et al. }(2004, \mathrm{UK})[60]\end{array}$ & CT scan & 27 AAA & Raghavan et al. & $\begin{array}{l}\text { - } 12 \text { ruptured and } 15 \text { non-ruptured } \\
\text { - Area of PWS correlated with rupture site on CT scan } \\
\text { - PWS significantly higher in ruptured AAA's }\end{array}$ \\
\hline $\begin{array}{l}\text { Vande Geest et al. } \\
(2006, \text { USA) [61] }\end{array}$ & CT scan & 13 AAA & $\begin{array}{l}\text { Anisotropic model/ILT } \\
\text { included }\end{array}$ & $\begin{array}{l}\text { - } 5 \text { non-ruptured repairs vs } 8 \text { ruptured repairs. } \\
\text { - Calculated rupture potential index from wall stress and } \\
\text { strength } \\
\text { - No significant difference in PWS }(P=0.62)\end{array}$ \\
\hline $\begin{array}{l}\text { Truijers et al. } \\
(2007, \mathrm{NL})[23]\end{array}$ & $\begin{array}{l}\text { Routine CT scan for } \\
\text { AAA (not done to } \\
\text { measure PWS) }\end{array}$ & $30(\mathrm{AAA}<5.5 \mathrm{~cm})$ & $\begin{array}{l}\text { patient specific } \\
\text { 3D/validated isotropic } \\
\text { nonlinear hyperelastic } \\
\text { material model }^{28-31}\end{array}$ & $\begin{array}{l}\text { - Aim was to assess PWS at maximal systolic blood } \\
\text { pressure as a promising technique to detect aneurysm } \\
\text { rupture risk. } \\
\text { - PWS analysis in asymptomatic, symptomatic and } \\
\text { ruptured AAA ( } 10 \text { patients per group). } \\
\text { - ILT and calcification were not included in PWS analysis. } \\
\text { - No significant difference between diameter of } \\
\text { asymptomatic, symptomatic or ruptured aneurysms } \\
\text { p=0.57). } \\
\text { PWS at maximal systolic blood pressure is significantly } \\
\text { higher in ruptured than asymptomatic aneurysms } \\
(\mathrm{p}=0.04) \text {. }\end{array}$ \\
\hline $\begin{array}{l}\text { Speelman L et al. } \\
(2007, \mathrm{NL})[62]\end{array}$ & $\begin{array}{l}\text { Location and extent } \\
\text { of calcification was } \\
\text { identified from } \\
\text { CT-scans }\end{array}$ & 6 patients & $\begin{array}{l}\text { A model was created } \\
\text { for each AAA and the } \\
\text { areas of calcification } \\
\text { were defined node-wise } \\
\text { in the mesh. }\end{array}$ & $\begin{array}{l}\text { Purpose was to evaluate the importance of material } \\
\text { properties of calcified AAA wall and determine } \\
\text { dependency of PWS on calcification. } \\
\text { - Calcification increases AAA wall stress. } \\
\text { - The stability of AAA is dependent more on the } \\
\text { location of calcification than the relative amount } \\
\text { of calcification. }\end{array}$ \\
\hline $\begin{array}{l}\text { Vande Geest et al. } \\
(2008, \text { USA) [63] }\end{array}$ & CT scan & 35 AAA & $\begin{array}{l}\text { Both anisotropic and } \\
\text { isotropic model }\end{array}$ & $\begin{array}{l}\text { - } 21 \text { elective and } 14 \text { emergency repairs (9 ruptured) } \\
\text { - Anisotropic model shows higher PWS than isotropic } \\
\text { model }(\mathrm{p}=0.001) \\
\text { - PWS not a significant predictor of AAA rupture }\end{array}$ \\
\hline $\begin{array}{l}\text { Heng et al. } \\
(2008, \text { UK) }[50]\end{array}$ & $\begin{array}{l}\text { Routinely performed } \\
\text { CT scans }\end{array}$ & $\begin{array}{l}70 \text { patients } \\
\text { (30 acute, } 40 \\
\text { elective) }\end{array}$ & blinded FEA & $\begin{array}{l}\text { - Purpose was to ascertain inter-operator and } \\
\text { intra-operator reliability. } \\
\text { - PWS was measured in acute/elective AAA. } \\
\text { - Potential limitations of their study which include: blood } \\
\text { pressure analysis, wall thickness, ILT, AAA tissue } \\
\text { properties, AAA decompression and site of rupture. } \\
\text { - PWS, but not maximal diameter, was significantly higher } \\
\text { in acute AAAs than in elective AAAs. } \\
\text { - Operator reliability acceptable. }\end{array}$ \\
\hline
\end{tabular}




\begin{tabular}{|c|c|c|c|c|}
\hline $\begin{array}{c}\text { Li ZY et al. } \\
(2008, \mathrm{UK})[64]\end{array}$ & $\begin{array}{l}\text { Patient-specific 3D } \\
\text { AAA geometries } \\
\text { were reconstructed } \\
\text { from CT images }\end{array}$ & 20 patients & $\begin{array}{l}\text { Non-linear large-strain } \\
\text { finite element model }\end{array}$ & $\begin{array}{l}\text { - Purpose was to see change in PWS in presence or } \\
\text { absence of ILT or calcification. } \\
\text { - Calcification increases AAA wall stress. } \\
\text { - In contrast, intra-luminal thrombus reduces the } \\
\text { maximum stress in AAA. }\end{array}$ \\
\hline $\begin{array}{l}\text { Bluestein D et al. } \\
(2009, \text { USA) [54] }\end{array}$ & $\begin{array}{l}\text { Patient-specific 3D } \\
\text { AAA geometries } \\
\text { were reconstructed } \\
\text { from CT images }\end{array}$ & 2 patients & $\begin{array}{l}\text { Uncoupled fluid } \\
\text { structure interaction } \\
\text { (FSI) approach was } \\
\text { applied in the presence } \\
\text { and absence of ILT. }\end{array}$ & $\begin{array}{l}\text { - Purpose was inclusion of ILT in stress analysis as it may } \\
\text { increase the accuracy of predicting AAA rupture risk. } \\
\text { - Two patients, with varied AAA geometries and ILT } \\
\text { structures were compared in detail. } \\
\text { - ILT appears to reduce stress. }\end{array}$ \\
\hline $\begin{array}{c}\text { Gasser TC et al. } \\
(2010, \text { Sweden) }[65]\end{array}$ & CT scan & 50 & Structural FE model & $\begin{array}{l}\text { - } 20 \text { ruptured and } 30 \text { elective AAA } \\
\text { PWS and peak wall rupture risk } 1.17(\mathrm{p}=0.021) \text { and } \\
1.43(\mathrm{p}=0.016) \text { times higher in ruptured than } \\
\text { diameter-matched non-ruptured aneurysms, } \\
\text { respectively. }\end{array}$ \\
\hline $\begin{array}{c}\text { Reeps C et al. } \\
(2010, \text { Germany) [66] }\end{array}$ & CT scan & 4 patients & $\begin{array}{l}\text { High-density hexahedral } \\
\text { FE model }\end{array}$ & $\begin{array}{l}\text { - } 3 \text { asymptomatic } \\
\text { - Purpose was to see impact of model assumptions on } \\
\text { PWS results } \\
\text { - Models with range of complexity }(1-7) \\
\text { - PWS could differ up to } 210 \% \text { individually and } 170 \% \text { on } \\
\text { average between simplistic and realistic models. }\end{array}$ \\
\hline $\begin{array}{l}\text { Larsson E et al. } \\
(2011, \text { Sweden })[67]\end{array}$ & CT scan & 30 patients & Structural FE model & $\begin{array}{l}\text { - } 15 \text { men and } 15 \text { women } \\
\text { - PWS did not differ in genders }\end{array}$ \\
\hline
\end{tabular}

Table 4. Studies reporting PET/CT in assessing aneurysm expansion and rupture.

\begin{tabular}{|c|c|c|c|}
\hline Author, year, Country & $\begin{array}{l}\text { Number of } \\
\text { patients }\end{array}$ & Key results & Comments \\
\hline $\begin{array}{l}\text { Sakalihasan et al. } \\
\text { (2002, Belgium) [72] }\end{array}$ & 26 AAA & $\begin{array}{c}\text { Uptake in AAA in } 10 \text { subjects and } 9 \text { required } \\
\text { emergency repair }\end{array}$ & $\begin{array}{l}\text { Possible correlation between FDG uptake and } \\
\text { triggering process leading to rupture }\end{array}$ \\
\hline $\begin{array}{l}\text { Sakalihasan et al. } \\
\text { (2004, Belgium) [73] }\end{array}$ & 26 AAA & $\begin{array}{c}\text { Uptake in AAA in } 10 \text { subjects and } 9 \text { required } \\
\text { emergency repair }\end{array}$ & $\begin{array}{l}\text { Possible correlation between FDG uptake and } \\
\text { triggering process leading to rupture }\end{array}$ \\
\hline $\begin{array}{l}\text { Truijers et al. } \\
\text { (2008, Netherlands) [77] }\end{array}$ & 34 AAA & $\begin{array}{l}\text { Aneurysmal uptake of FDG was higher then normal } \\
\text { aorta in controls (SUV } 2.5 \pm 0.52 \text { versus } 1.78 \pm 0.45 \text {, } \\
\text { respectively; } \mathrm{p}=0.001) \text { There was no correlation } \\
\text { between statin intake and FDG uptake There was not } \\
\text { correlation between maximal aneurysmal diameter and } \\
\text { FDG level }(\mathrm{r}=0.09,95 \% \mathrm{CI}-0.42-0.56 ; 0.7)\end{array}$ & $\begin{array}{l}\text { FDG uptake identifies inflammation of } \\
\text { aneurysm wall irrespective of aneurysm size. } \\
\text { Asymptomatic aneurysms have more FDG and } \\
\text { inflammatory activity in wall than normal aorta. }\end{array}$ \\
\hline $\begin{array}{l}\text { Reeps et al. } \\
\text { (2008, Germany) [75] }\end{array}$ & 15 AAA & $\begin{array}{l}\text { Symptomatic aneurysms had higher PET uptake vs. } \\
\text { asymptomatic (SUVmax, } 3.5 \pm 0.6 \text { vs } 7.5 \pm 3 \text {; } \\
\mathrm{P}<0.001 \text { ) FDG uptake was related to higher } \\
\text { inflammatory cell infiltrate, specifically } \\
\text { macrophage/T-cell infiltration, MMP9 expression, } \\
\text { decreasing collagen content and VSMC density. }\end{array}$ & $\begin{array}{c}\text { FDG PETCT correlates to histopathological } \\
\text { characteristics of aneurysm wall instability and } \\
\text { inflammation. It may allow improved prediction } \\
\text { of individual risk of rupture. }\end{array}$ \\
\hline $\begin{array}{c}\text { Kotez et al. } \\
(2009, \text { UK) }[78]\end{array}$ & $\mathrm{N}=14 \mathrm{AAA}$ & $\begin{array}{c}12 / 14(85.7 \%) \text { aneurysms had high FDG uptake } \\
\text { SUV }>2.5 \text { There was no correlation between FDG } \\
\text { uptake and calcification } 2 / 14 \text { patients had inflammatory } \\
\text { aneurysms }(\mathrm{P}=0.04) \text {. }\end{array}$ & $\begin{array}{l}\text { There is In vivo evidence demonstrating PET } \\
\text { tracer uptake correlates with increased glucose } \\
\text { metabolism in aneurysms. This may predict } \\
\text { aneurysm development. }\end{array}$ \\
\hline $\begin{array}{c}\text { Xu et al. } \\
(2010, \mathrm{UK})[57]\end{array}$ & 5 AAA & $\begin{array}{l}\text { High wall shear stress co-localized with areas of } \\
\text { 18F-FDG uptake } 2 \text { patients ruptured the aneurysm at } \\
\text { site of highest metabolic activity and wall stress. }\end{array}$ & $\begin{array}{l}\text { Metabolically active aneurysms have high wall } \\
\text { stress and this correlates to clinical progression. } \\
\text { Further larger studies are needed to validate this. }\end{array}$ \\
\hline $\begin{array}{l}\text { Kotez et al. } \\
(2011, \mathrm{UK}) \text { [79] }\end{array}$ & 34 patients & $\begin{array}{l}\text { Full data available on } \mathrm{N}=25 / 34(73.5 \%) \text { Median aortic } \\
\text { SUVmax was } 1.70 \text {, with aortic target to background } \\
\text { ratio of } 1.15 \text {. Over } 12 \text { months median aneurysm growth } \\
\text { was } 2.0 \mathrm{~mm} \text {. Correlation (r) between PET tracer F-FDG } \\
\text { SUVmax and aneurysm expansion at } 12 \text { months was } \\
\qquad-0.501(\mathrm{p}=0.011)\end{array}$ & $\begin{array}{c}\text { The observational longitudinal study } \\
\text { demonstrated an inverse trend between FDG } \\
\text { uptake and AAA expansion. }\end{array}$ \\
\hline
\end{tabular}


tudinal pilot study suggest that there is an inverse trend between FDG uptake on PET and future AAA expansion. Aortic aneurysms with lower metabolic activity may therefore be more likely to expand [79].

More accurate studies with larger numbers of patients are needed to determine the true value of FDG uptake. New PET/CT tracers that are more specific are being developed and will be available in the future for human use. These will be targeted towards processes known to be important the aneurysm development and rupture, for example to image MMP activity or specific cellular infiltration of the wall, and may therefore become powerful In vivo tools to assess the mechanisms and progress of the disease.

\section{Role of Magnetic Resonance Imaging (MRI) to Measure Aortic PWV, Distensibility and Compliance}

Pulse wave velocity is a measure of the time taken by the pulse pressure wave to travel over a specific distance of artery [10]. The more stiff the wall of the artery, the faster the wave moves. It is calculated as the distance between two measurement points (usually the common carotid and femoral arteries) divided by the time shift to the waveforms from these two points [10]. The measurement of PWV is a simple, non-invasive and reproducible method to determine arterial stiffness [10]. Stiffness of the arterial wall is mainly determined by the matrix components of the wall, i.e., the elastin, collagen, and smooth muscle cells [11]. It is discussed above how PWV is distinct from pressure strain modulus (Table 1). A study on aneurysm specimens showed that aortic wall thickness or stiffness may be a better predictor of rupture for large AAAs [80].

Carotid femoral PWV (or aortic PWV) is considered the gold standard measurement of arterial stiffness [10]. Alternatively brachial-ankle pulse wave velocity (baPWV) can be measured and this provides qualitatively similar information as aortic PWV and is a well-established index of central arterial stiffness [12]. PWV can be measured by non invasive methods based on pressure sensors [81] or Doppler probes [10] and MRI [13]. Aortic PWV is now known to be an independent predictor of cardiovascular mortality in subjects older than 70 years; a $1 \mathrm{~m} / \mathrm{s}$ increase in PWV increased cardiovascular mortality by $19 \%[82]$.

The propagation of the pulse wave is inversely related to the distensibility of the arterial tube. In a dilated vessel the PWV is decreased and this corresponds to an increase in compliance. PWV is more easily measured property than true compliance, which requires an intra-arterial pressure measurement to relate to the corresponding change in arterial cross sectional area and this cannot be obtained non-invasively. Peripheral blood pressure can be used to calculate compliance but this underestimates the true intra-aneurysmal systolic pressure by $5 \%$ and overestimates diastolic blood pressure by $12 \%$ [15].

A change in pulse wave velocity along the segments of aorta may detect changes in local compliance that are a precursor of aneurysm formation even before a change in aortic diameter or other anatomical changes occur [11]. In one small study, a high thoracic aortic compliance was related to faster growth of the AAA and earlier rupture [37]. Phase contrast MRI can also be used to measure compliance in aortic aneurysms [83,84]. The role of PWV, distension and compliance measurements are yet to be validated in prediction models of AAA. MRI however is a reliable tool in AAA evaluation, 3D contrast enhanced MR angiography is accurate in defining the location, extent, diameter and exact morphology of aneurysms and the relationship to aortic branch vessels and surrounding structures. MRI also displays ILT as intermediate signal change on standard T1-weighted images but not aortic calcification. However, slow intra-luminal flow may be difficult to differentiate from ILT. This may be over come with the use of spin-echo with gradient recalled echo (GRE) cine MR or MRA with gadolinium contrast [85]. Other recent MR techniques that may provide enhanced resolution and flow information include fast imaging employed steady-state acquisition (FIESTA) and balanced steady state free precession [86]. The contrast enhancement is performed on the basis of T2 to T1 ratio rather than inflow effects or gradient echo methods. MRI is beneficial in terms of lack of ionizing radiation and this specially applies to patients who are severely allergic to iodinated contrast media used for $\mathrm{CT}$, or at a high risk of developing renal failure due to contrast nephropathy. MRI also provides ideal image modality in terms of reproducibility with low inter-observer error for diagnosis and monitoring AAA expansion overtime.

\subsection{The Emerging Role of Functional Imaging in Aneurysm Progression}

As discussed above, aneurysm enlargement has been associated with growth of intra-luminal thrombus [47]. This thrombus is biologically active with constant turnover due to platelet activation and phosphatidylserine exposure at the interface with circulating blood [87]. 99 mTc-annexin-V (ANX) is a tracer that binds to phosphatidylserine on the surface of activated platelets demonstrated in experimental aneurysms and ex vivo in human AAA thrombus samples following open repair [88]. ANX imaging may become a non-invasive tool for providing functional information on mural thrombus activity, 
which may be relevant to subsequent AAA growth.

\subsection{Nano-Particles and Aneurysm Progression}

Nano-particles, for example ultra-small super paramagnetic iron oxide particles (USPIO), have a variety of applications in molecular and cellular imaging but so far these have not been used in human AAA imaging. USPIO enhanced MR imaging has been used in vivo to identify inflammation in human carotid plaques with increased accumulation of USPIO within macrophages [89]. USPIO may be useful as a surrogate for detecting the acute inflammatory activity involved in the development of abdominal aneurysms [90]. In a pilot study, uptake of USPIO in abdominal aortic aneurysms appears to distinguish those patients with more rapidly progressive abdominal aortic aneurysm expansion [91].

\section{Conclusions}

Aneurysmal disease has a complex natural course and our knowledge of the events that lead to aneurysm rupture is incomplete. AAA enlargement is related to remodeling of the extracellular matrix, particularly collagen and elastin metabolism whilst there is general consensus that ruptures are a multi-factorial process involveing both mechanical forces and local cellular activity and remodeling. Non-invasive imaging modalities offer the possibility of more accurate risk assessment than simply diagnosis and periodic size measurement. Some of these additional assessments could be included with aneurysm size surveillance but more evidence is needed to know whether this will offer any survival benefit and whether they would be cost-effective. The non invasive and functional imaging techniques discussed in this review offer highly promising methods to improve our ability to accurately identify aneurysms at risk of rupture.

The techniques outlined in this review allow not only delineation of aneurysm morphology but also allow assessment of physiological and metabolic activity. These imaging modalities need to be incorporated in the clinical management algorithm for aneurysm patients. Further work is required to understand the multiple factors associated with aneurysm rupture because some patients with small aneurysms in screening programmes still face the threat of aneurysm rupture and mortality.

\section{Message for the Clinic}

Abdominal aortic aneurysm screening is being adapted in many countries and this will increase the number of known small AAA. We cannot predict outcome of small AAA and current literature supports surveillance as a safest option. Wide large-scale validation of physiological measurements of aneurysms (including finite element analysis, intra-luminal thrombus, distensibility and compliance), PET/CT and $\mathrm{PMRI}$ is now awaited.

\section{REFERENCES}

[1] D. A. Vorp and J. P. V. Geest, "Biomechanical Determinants of Abdominal Aortic Aneurysm Rupture," Arteriosclerosis, Thrombosis, and Vascular Biology, Vol. 25, No. 8, 2005, pp. 1558-1566. doi:10.1161/01.ATV.0000174129.77391.55

[2] The UK Small Aneurysm Trial Participants, "Mortality Results for Randomised Controlled Trial of Early Elective Surgery or Ultrasonographic Surveillance for Small Abdominal Aortic Aneurysms. The UK Small Aneurysm Trial Participants," Lancet, Vol. 352, No. 9141, 1998, pp. 1649-1655.

[3] F. A. Lederle, S. E. Wilson, G. R. Johnson, D. B. Reinke, F. N. Littooy, C. W. Acher, D. J. Ballard, L. M. Messina, I. L. Gordon, E. P. Chute, W. C. Krupski, S. J. Busuttil, G. W. Barone, S. Sparks, L. M. Graham, J. H. Rapp, M. S. Makaroun, G. L. Moneta, R. A. Cambria, R. G. Makhoul, D. Eton, H. J. Ansel, J. A. Freischlag and D. Bandyk, "Immediate Repair Compared with Surveillance of Small Abdominal Aortic Aneurysms," The New England Journal of Medicine, Vol. 346, No. 19, 2002, pp. 1437-1444. doi:10.1056/NEJMoa012573

[4] C. K. Zarins, T. Crabtree, D. A. Bloch, F. R. Arko, K. Ouriel and R. A. White, "Endovascular Aneurysm Repair at 5 Years: Does Aneurysm Diameter Predict Outcome?" Journal of Vascular Surgery, Vol. 44, No. 5, 2006, pp. 920-929. doi:10.1016/j.jvs.2006.06.048

[5] H. A. Ashton, M. J. Buxton, N. E. Day, L. G. Kim, T. M. Marteau, R. A. Scott, S. G. Thompson and N. M. Walker, "The Multicentre Aneurysm Screening Study (MASS) into the Effect of Abdominal Aortic Aneurysm Screening on Mortality in Men: A Randomised Controlled Trial," Lancet, Vol. 360, No. 9345, 2002, pp. 1531-1539.

[6] R. C. Darling, C. R. Messina, D. C. Brewster and L. W. Ottinger, "Autopsy Study of Unoperated Abdominal Aortic Aneurysms. The Case for Early Resection," Circulation, Vol. 56, No. S3, 1977, pp. II161-II164.

[7] S. C. Nicholls, J. B. Gardner, M. H. Meissner and H. K. Johansen, "Rupture in Small Abdominal Aortic Aneurysms," Journal of Vascular Surgery, Vol. 28, No. 5, 1998, pp. 884-888. doi:10.1016/S0741-5214(98)70065-5

[8] P. Cao, P. De Rango, F. Verzini, G. Parlani, L. Romano and E. Cieri, "Comparison of Surveillance versus Aortic Endografting for Small Aneurysm Repair (CAESAR): Results from a Randomised Trial," European Journal of Vascular and Endovascular Surgery, Vol. 41, No. 1, 2011, pp. 13-25. doi:10.1016/j.ejvs.2010.08.026

[9] K. Ouriel, D. G. Clair, K. C. Kent and C. K. Zarins, "Endovascular Repair Compared with Surveillance for Patients with Small Abdominal Aortic Aneurysms," Journal of Vascular Surger, Vol. 51, No. 5, 2010, pp. 1081-1087.

[10] S. Laurent, J. Cockcroft, B. L. Van, P. Boutouyrie, C. Giannattasio, D. Hayoz, B. Pannier, C. Vlachopoulos, I. 
Wilkinson and H. Struijker-Boudier, "Expert Consensus Document on Arterial Stiffness: Methodological Issues and Clinical Applications," European Heart Journal, Vol. 27, No. 21, 2006, pp. 2588-2605. doi:10.1093/eurheartj/ehl254

[11] J. Luo, K. Fujikura, L. S. Tyrie, M. D. Tilson and E. E. Konofagou, "Pulse Wave Imaging of Normal and Aneurysmal Abdominal Aortas in vivo," IEEE Transactions on Medical Imaging, Vol. 28, No. 4, 2009, pp. 477-486. doi:10.1109/TMI.2008.928179

[12] J. Sugawara, K. Hayashi, T. Yokoi, M. Y. Cortez-Cooper, A. E. DeVan, M. A. Anton and H. Tanaka, "BrachialAnkle Pulse Wave Velocity: An Index of Central Arterial Stiffness?" Journal of Human Hypertension, Vol. 19, No. 5, 2005, pp. 401-406. doi:10.1038/sj.jhh.1001838

[13] W. J. Rogers, Y. L. Hu, D. Coast, D. A. Vido, C. M. Kramer, R. E. Pyeritz and N. Reichek, "Age-Associated Changes in Regional Aortic Pulse Wave Velocity," Journal of the American College of Cardiology, Vol. 38, No. 4, 2001, pp. 1123-1129. doi:10.1016/S0735-1097(01)01504-2

[14] A. Long, L. Rouet, A. Bissery, P. Rossignol, D. Mouradian and M. Sapoval, "Compliance of Abdominal Aortic Aneurysms Evaluated by Tissue Doppler Imaging: Correlation with Aneurysm Size," Journal of Vascular Surgery, Vol. 42, No. 1, 2005, pp. 18-26. doi:10.1016/j.jvs.2005.03.037

[15] M. van't Veer, J. Buth, M. Merkx, P. Tonino, H. van den Bosch, N. Pijls and F. de van Vosse, "Biomechanical Properties of Abdominal Aortic Aneurysms Assessed by Simultaneously Measured Pressure and Volume Changes in Humans," Journal of Vascular Surgery, Vol. 48, No. 6, 2008, pp. 1401-1407.

[16] M. Ganten, U. Krautter, W. Hosch, J. Hansmann, H. von Tengg-Kobligk, S. Delorme, H. U. Kauczor, G. W. Kauffmann and M. Bock, "Age Related Changes of Human Aortic Distensibility: Evaluation with ECG-Gated CT," European Radiology, Vol. 17, No. 3, 2007, pp. 701- 708. doi:10.1007/s00330-006-0309-Z

[17] M. K. Ganten, U. Krautter, H. von Tengg-Kobligk, D. Bockler, H. Schumacher, W. Stiller, S. Delorme, H. U. Kauczor, G. W. Kauffmann and M. Bock, "Quantification of Aortic Distensibility in Abdominal Aortic Aneurysm Using ECG-Gated Multi-Detector Computed Tomography," European Radiology, Vol. 18, No. 5, 2008, pp. 966-973. doi:10.1007/s00330-007-0833-5

[18] P. J. van, K. L. Vincken, S. M. Sprinkhuizen, M. A. Viergever, J. W. van Keulen, J. A. van Herwaarden, F. L. Moll and L. W. Bartels, "Aortic Pulsatile Distention in Young Healthy Volunteers Is Asymmetric: Analysis with ECG-Gated MRI," European Journal of Vascular and Endovascular Surgery, Vol. 37, No. 2, 2009, pp. 168-174.

[19] K. Wilson, A. Bradbury, M. Whyman, P. Hoskins, A. Lee, G. Fowkes, P. McCollum and C. V. Ruckley, "Relationship between Abdominal Aortic Aneurysm Wall Compliance and Clinical Outcome: A Preliminary Analysis," European Journal of Vascular and Endovascular Surgery,
Vol. 15, No. 6, 1998, pp. 472-477. doi:10.1016/S1078-5884(98)80105-6

[20] K. A. Wilson, A. J. Lee, A. J. Lee, P. R. Hoskins, F. G. Fowkes, C. V. Ruckley and A. W. Bradbury, "The Relationship between Aortic Wall Distensibility and Rupture of Infrarenal Abdominal Aortic Aneurysm," Journal of Vascular Surgery, Vol. 37, No. 1, 2003, pp. 112-117. doi:10.1067/mva.2003.40

[21] M. F. Fillinger, M. L. Raghavan, S. P. Marra, J. L. Cronenwett and F. E. Kennedy, "In Vivo Analysis of Mechanical Wall Stress and Abdominal Aortic Aneurysm Rupture Risk," Journal of Vascular Surgery, Vol. 36, No. 3, 2002, pp. 589-597. doi:10.1067/mva.2002.125478

[22] M. F. Fillinger, S. P. Marra, M. L. Raghavan and F. E. Kennedy, "Prediction of Rupture Risk in Abdominal Aortic Aneurysm during Observation: Wall Stress versus Diameter," Journal of Vascular Surgery, Vol. 37, No. 4, 2003, pp. 724-732. doi:10.1067/mva.2003.213

[23] M. Truijers, J. A. Pol, L. J. Schultzekool, S. M. van Sterkenburg, M. F. Fillinger and J. D. Blankensteijn, "Wall Stress Analysis in Small Asymptomatic, Symptomatic and Ruptured Abdominal Aortic Aneurysms," European Journal of Vascular and Endovascular Surgery, Vol. 33, No. 4, 2007, pp. 401-407. doi:10.1016/j.ejvs.2006.10.009

[24] J. Higgins, "Cochrane Handbook for Systemmtic Reviews of Interventions," 2009.

http://www.cochrane.org/training/cochrane-handbook

[25] Oxford Centre for Evidence-based Medicine-Levels of Evidence (March 2009) http://www.cebm.net/index.aspx?o=1025.

[26] R. Thompson, J. A. Cooper, H. A. Ashton and H. Hafez, "Growth Rates of Small Abdominal Aortic Aneurysms Correlate with Clinical Events," British Journal of Surgery, Vol. 97, No. 1, 2010, pp. 37-44. doi:10.1002/bjs.6779

[27] J. Collin, "Screening for Abdominal Aortic Aneurysms," British Journal of Surgery, Vol. 72, No. 11, 1985, pp. 851-852. doi:10.1002/bjs.1800721102

[28] W. J. Flu, J. P. van Kuijk, E. J. Merks, R. Kuiper, H. J. Verhagen, J. G. Bosch, N. Bom, J. J. Bax and D. Poldermans, "Screening for Abdominal Aortic Aneurysms Using a Dedicated Portable Ultrasound System: Early Results," European Journal of Echocardiography, Vol. 10, No. 5, 2009, pp. 602-606. doi:10.1093/ejechocard/jep081

[29] L. R. Sprouse, G. H. Meier, III, C. J. Lesar, R. J. Demasi, J. Sood, F. N. Parent, M. J. Marcinzyck and R. G. Gayle, "Comparison of Abdominal Aortic Aneurysm Diameter Measurements Obtained with Ultrasound and Computed Tomography: Is There a Difference?," Journal of Vascular Surgery, Vol. 38, No. 3, 2003, pp. 466-471. doi:10.1016/S0741-5214(03)00367-7

[30] R. A. Scott, P. V. Tisi, H. A. Ashton and D. R. Allen, "Abdominal Aortic Aneurysm Rupture Rates: A 7-Year Follow-up of the Entire Abdominal Aortic Aneurysm Population Detected by Screening," Journal of Vascular Surgery, Vol. 28, No. 1, 1998, pp. 124-128. 
doi:10.1016/S0741-5214(98)70207-1

[31] S. T. MacSweeney, G. Young, R. M. Greenhalgh and J. T. Powell, "Mechanical Properties of the Aneurysmal Aorta," British Journal of Surgery, Vol. 79, No. 12, 1992, pp. 1281-1284. doi:10.1002/bjs.1800791211

[32] K. A. Wilson, P. R. Hoskins, A. J. Lee, F. G. Fowkes, C. V. Ruckley and A. W. Bradbury, "Ultrasonic Measurement of Abdominal Aortic Aneurysm Wall Compliance: A Reproducibility Study," Journal of Vascular Surgery, Vol. 31, No. 3, 2000, pp. 507-513. doi:10.1016/S0741-5214(00)90312-4

[33] A. Hoegh and J. S. Lindholt, "Basic Science Review. Vascular Distensibility as a Predictive Tool in the Management of Small Asymptomatic Abdominal Aortic Aneurysms," Vascular and Endovascular Surgery, Vol. 43, No. 4, 2009, pp. 333-338. doi:10.1177/1538574409336019

[34] G. Agarwal, G. Mozes, R. R. Kinnick, P. Gloviczki, R. E. Bruhnke, M. Carmo, T. L. Hoskin, K. E. Bennett and J. L. Greenleaf, "Vibrometry: A Novel Noninvasive Application of Ultrasonographic Physics to Estimate Wall Stress in Native Aneurysms," Annals of the New York Academy of Sciences, Vol. 1085, 2006, pp. 197-207. doi:10.1196/annals.1383.001

[35] K. Wilson, M. Whyman, P. Hoskins, A. J. Lee, A. W. Bradbury, F. G. Fowkes and C. V. Ruckley, "The Relationship between Abdominal Aortic Aneurysm Wall Compliance, Maximum Diameter and Growth Rate," Cardiovascular Surgery, Vol. 7, No. 2, 1999, pp. 208-213. doi:10.1016/S0967-2109(98)00041-6

[36] A. Long, L. Rouet, A. Bissery, P. Rossignol, D. Mouradian and M. Sapoval, "Compliance of Abdominal Aortic Aneurysms: Evaluation of Tissue Doppler Imaging," Ultrasound in Medicine and Biology, Vol. 30, No. 9, 2004, pp. 1099-1108. doi:10.1016/j.ultrasmedbio.2004.08.007

[37] L. Russo, "Thoracic Aortic Compliance as a Determinant of Rupture of Abdominal Aortic Aneurysms," Annals of the New York Academy of Sciences, Vol. 1085, 2006, pp. 363-366. doi:10.1196/annals.1383.026

[38] K. Fujikura, J. Luo, V. Gamarnik, M. Pernot, R. Fukumoto, M. D. Tilson, III and E. E. Konofagou, "A Novel Noninvasive Technique for Pulse-Wave Imaging and Characterization of Clinically-Significant Vascular Mechanical Properties in vivo," Ultrasonic Imaging, Vol. 29, No. 3, 2007, pp. 137-154.

[39] J. Luo, K. Fujikura, L. S. Tyrie, M. D. Tilson and E. E. Konofagou, "Pulse Wave Imaging of Human Abdominal Aortas in Vivo," Proceeding of IEEE Ultrasonics Symposium, Beijing, 2008, pp. 859-862.

[40] J. W. Luo, K. Fujikura, L. S. Tyrie, M. D. Tilson and E. E. Konofagou, "Pulse Wave Imaging of Abdominal Aortic Aneurysms: Comparison Between Control and Angiotensin II-Treated Mice in Vivo," 2008 IEEE International Ultrasonics Symposium, Beijing, 2-5 November 2008, pp. 985-988.

[41] K. I. Paraskevas, N. Bessias, C. Psathas, K. Akridas, T.
Dragios, G. Nikitas, V. Andrikopoulos, D. P. Mikhailidis and Z. S. Kyriakides, "Evaluation of Aortic Stiffness (Aortic Pulse-Wave Velocity) before and after Elective Abdominal Aortic Aneurysm Repair Procedures: A Pilot Study," Open Cardiovascular Medicine Journal, Vol. 3, 2009, pp. 173-175.

[42] S. Makita, A. Ohira, R. Tachieda, S. Itoh, Y. Moriai, H. Niinuma, M. Nakamura and K. Hiramori, "Dilation and Reduced Distensibility of Carotid Artery in Patients with Abdominal Aortic Aneurysms," American Heart Journal, Vol. 140, No. 2, 2000, pp. 297-302. doi: $10.1067 / \mathrm{mhj} .2000 .108000$

[43] K. A. Wilson, J. S. Lindholt, P. R. Hoskins, L. Heickendorff, S. Vammen and A. W. Bradbury, "The Relationship between Abdominal Aortic Aneurysm Distensibility and Serum Markers of Elastin and Collagen Metabolism," European Journal of Vascular and Endovascular Surgery, Vol. 21, No. 2, 2001, pp. 175-178. doi:10.1053/ejvs.2001.1303

[44] L. P. Harter, B. H. Gross, P. W. Callen and R. A. Barth, "Ultrasonic Evaluation of Abdominal Aortic Thrombus," Journal of Ultrasound in Medicine, Vol. 1, No. 8, 1982, pp. 315-318.

[45] M. Kazi, J. Thyberg, P. Religa, J. Roy, P. Eriksson, U. Hedin and J. Swedenborg, "Influence of Intraluminal Thrombus on Structural and Cellular Composition of Abdominal Aortic Aneurysm Wall," Journal of Vascular Surgery, Vol. 38, No. 6, 2003, pp. 1283-1292. doi:10.1016/S0741-5214(03)00791-2

[46] G. W. Schurink, J. M. van Baalen, M. J. Visser and J. H. van Bockel, "Thrombus within an Aortic Aneurysm Does not Reduce Pressure on the Aneurysmal Wall," Journal of Vascular Surgery, Vol. 31, No. 3, 2000, pp. 501-506. doi:10.1016/S0741-5214(00)90311-2

[47] J. Stenbaek, B. Kalin and J. Swedenborg, "Growth of Thrombus May be a Better Predictor of Rupture than Diameter in Patients with Abdominal Aortic Aneurysms," European Journal of Vascular and Endovascular Surgery, Vol. 20, No. 5, 2000, pp. 466-469. doi:10.1053/ejvs.2000.1217

[48] H. G. Beebe and B. Kritpracha, "Imaging of Abdominal Aortic Aneurysm: Current Status," Annals of Vascular Surgery, Vol. 17, No. 1, 2003, pp. 111-118. doi:10.1007/s10016-001-0345-8

[49] W. R. Mower, L. J. Baraff and J. Sneyd, "Stress Distributions in Vascular Aneurysms: Factors Affecting Risk of Aneurysm Rupture," Journal of Surgical Research, Vol. 55, No. 2, 1993, pp. 155-161. doi:10.1006/jsre.1993.1123

[50] M. S. Heng, M. J. Fagan, J. W. Collier, G. Desai, P. T. McCollum and I. C. Chetter, "Peak Wall Stress Measurement in Elective and Acute Abdominal Aortic Aneurysms," Journal of Vascular Surgery, Vol. 47, No. 1, 2008, pp. 17-22. doi:10.1016/j.jvs.2007.09.002

[51] M. L. Raghavan, D. A. Vorp, M. P. Federle, M. S. Makaroun and M. W. Webster, "Wall Stress Distribution on Three-Dimensionally Reconstructed Models of Human Abdominal Aortic Aneurysm," Journal of Vascular Sur- 
gery, Vol. 31, No. 4, 2000, pp. 760-769. doi:10.1067/mva.2000.103971

[52] M. L. Raghavan and D. A. Vorp, "Toward a Biomechanical Tool to Evaluate Rupture Potential of abdominal Aortic Aneurysm: Identification of a finite Strain Constitutive Model and Evaluation of Its Applicability," Journal of Biomechanics, Vol. 33, No. 4, 2000, pp. 475-482.

[53] D. A. Vorp, M. L. Raghavan, S. C. Muluk, M. S. Makaroun, D. L. Steed, R. Shapiro and M. W. Webster, "Wall Strength and Stiffness of Aneurysmal and Nonaneurysmal Abdominal Aorta," Annals of the New York Academy of Sciences, Vol. 800, 1996, pp. 274-276. doi:10.1111/j.1749-6632.1996.tb33330.x

[54] D. Bluestein, K. Dumont, B. M. De, J. Ricotta, P. Impellizzeri, B. Verhegghe and P. Verdonck, "Intraluminal Thrombus and Risk of Rupture in Patient Specific Abdominal Aortic Aneurysm-FSI Modelling," Computer Methods in Biomechanics and Biomedical Engineering, Vol. 12, No. 1, 2009, pp. 73-81. doi:10.1080/10255840802176396

[55] L. Speelman, A. Bohra, E. M. Bosboom, G. W. Schurink, F. N. van de Vosse, M. S. Makaorun and D. A. Vorp, "Effects of Wall Calcifications in Patient-Specific Wall Stress Analyses of Abdominal Aortic Aneurysms," Journal of Biomechanical Engineering, Vol. 129, No. 1, 2007, pp. 105-109.

[56] Z. Y. Li, J. King-Im, T. Y. Tang, E. Soh, T. C. See and J. H. Gillard, "Impact of Calcification and Intraluminal Thrombus on the Computed Wall Stresses of Abdominal Aortic Aneurysm," Journal of Vascular Surgery, Vol. 47, No. 5, 2008, pp. 928-935. doi:10.1016/j.jvs.2008.01.006

[57] X. Y. Xu, A. Borghi, A. Nchimi, J. Leung, P. Gomez, Z. Cheng, J. O. Defraigne and N. Sakalihasan, "High Levels of 18F-FDG Uptake in Aortic Aneurysm Wall Are Associated with High Wall Stress," European Journal of Vascular and Endovascular Surgery, Vol. 39, No. 3, 2010, pp. 295-301. doi:10.1016/j.ejvs.2009.10.016

[58] H. S. Flora, B. Talei-Faz, L. Ansdell, E. J. Chaloner, A. Sweeny, A. Grass and M. Adiseshiah, "Aneurysm Wall Stress and Tendency to Rupture Are Features of Physical Wall Properties: An Experimental Study," Journal of Endovascular Therapy, Vol. 9, No. 5, 2002, pp. 665-675. doi:10.1583/1545-1550(2002)009<0665:AWSATT $>2.0$.C $\mathrm{O} ; 2$

[59] D. E. Szilagyi, R. F. Smith, F. J. DeRusso, J. P. Elliott and F. W. Sherrin, "Contribution of Abdominal Aortic Aneurysmectomy to Prolongation of Life," Annals of Surgery, Vol. 164, No. 4, 1966, pp. 678-699. doi:10.1097/00000658-196610000-00014

[60] K. Venkatasubramaniam, M. J. Fagan, T. Mehta, K. J. Mylankal, B. Ray, G. Kuhan, I. C. Chetter and P. T. McCollum, "A Comparative Study of Aortic Wall Stress Using Finite Element Analysis for Ruptured and NonRuptured Abdominal Aortic Aneurysms," European Journal of Vascular and Endovascular Surgery, Vol. 28, No. 2, 2004, pp. 168-176.

[61] J. P. Vande Geest, E. S. Di Martino, A. Bohra, M. S.
Makaroun and D. A. Vorp, "A Biomechanics-Based Rupture Potential Index for Abdominal Aortic Aneurysm Risk Assessment: Demonstrative Application," Annals of the New York Academy of Sciences, Vol. 1085, 2006, pp. 11-21. doi:10.1196/annals.1383.046

[62] L. Speelman, A. Bohra, E. M. Bosboom, G. W. Schurink, F. N. van de Vosse, M. S. Makaorun and D. A. Vorp, "Effects of Wall Calcifications in Patient-Specific Wall Stress Analyses of Abdominal Aortic Aneurysms," Journal of Biomechanical Engineering, Vol. 129, No. 1, 2007, pp. 105-109.

[63] J. P. Vande Geest, D. E. Schmidt, M. S. Sacks and D. A. Vorp, "The Effects of Anisotropy on the Stress Analyses of Patient-Specific Abdominal Aortic Aneurysms," Annals of Biomedical Engineering, Vol. 36, No. 6, 2008, pp. 921-932.

[64] Z. Y. Li, J. King-Im, T. Y. Tang, E. Soh, T. C. See and J. H. Gillard, "Impact of Calcification and Intraluminal Thrombus on the Computed Wall Stresses of Abdominal Aortic Aneurysm," Journal of Vascular Surgery, Vol. 47, No. 5, 2008, pp. 928-935. doi:10.1016/j.jvs.2008.01.006

[65] T. C. Gasser, M. Auer, F. Labruto, J. Swedenborg and J. Roy, "Biomechanical Rupture Risk Assessment of Abdominal Aortic Aneurysms: Model Complexity versus Predictability of Finite Element Simulations," European Journal of Vascular and Endovascular Surgery, Vol. 40, No. 2, 2010, pp. 176-185. doi:10.1016/j.ejvs.2010.04.003

[66] C. Reeps, M. Gee, A. Maier, M. Gurdan, H. H. Eckstein and W. A. Wall, "The Impact of Model Assumptions on Results of Computational Mechanics in Abdominal Aortic Aneurysm," Journal of Vascular Surgery, Vol. 51, No. 3, 2010, pp. 679-688. doi:10.1016/j.jvs.2009.10.048

[67] E. Larsson, F. Labruto, T. C. Gasser, J. Swedenborg and R. Hultgren, "Analysis of Aortic Wall Stress and Rupture Risk in patients with Abdominal Aortic Aneurysm with a Gender Perspective," Journal of Vascular Surgery, Vol. 54, No. 2, 2011, pp. 295-299. doi:10.1016/j.jvs.2010.12.053

[68] M. Tatsumi, C. Cohade, Y. Nakamoto and R. L. Wahl, "Fluorodeoxyglucose Uptake in the Aortic Wall at PET/CT: Possible Finding for Active Atherosclerosis," Radiology, Vol. 229, No. 3, 2003, pp. 831-837.

[69] N. Sakalihasan, R. Hustinx and R. Limet, "Contribution of PET Scanning to the Evaluation of Abdominal Aortic Aneurysm," Seminars in Vascular Surgery, Vol. 17, No. 2, 2004, pp. 144-153. doi:10.1053/j.semvascsurg.2004.03.002

[70] E. Choke, G. Cockerill, W. R. Wilson, S. Sayed, J. Dawson, I. Loftus and M. M. Thompson, "A review of Biological Factors Implicated in Abdominal Aortic Aneurysm Rupture," European Journal of Vascular and Endovascular Surgery, Vol. 30, No. 3, 2005, pp. 227-244. doi:10.1016/j.ejvs.2005.03.009

[71] S. R. Vallabhaneni, G. L. Gilling-Smith, T. V. How, S. D. Carter, J. A. Brennan and P. L. Harris, "Heterogeneity of Tensile Strength and Matrix Metalloproteinase Activity in the Wall of Abdominal Aortic Aneurysms," Journal of 
Endovascular Therapy, Vol. 11, No. 4, 2004, pp. 494-502. doi:10.1583/04-1239.1

[72] N. Sakalihasan, D. H. Van, P. Gomez, P. Rigo, C. M. Lapiere, B. Nusgens and R. Limet, "Positron Emission Tomography (PET) Evaluation of Abdominal Aortic Aneurysm (AAA)," European Journal of Vascular and Endovascular Surgery, Vol. 23, No. 5, 2002, pp. 431-436. doi:10.1053/ejvs.2002.1646

[73] N. Sakalihasan, R. Hustinx and R. Limet, "Contribution of PET Scanning to the Evaluation of Abdominal Aortic Aneurysm," Seminars in Vascular Surgery, Vol. 17, No. 2, 2004, pp. 144-153. doi:10.1053/j.semvascsurg.2004.03.002

[74] M. Nahrendorf, E. Keliher, B. Marinelli, F. Leuschner, C. S. Robbins, R. E. Gerszten, M. J. Pittet, F. K. Swirski and R. Weissleder, "Detection of Macrophages in Aortic Aneurysms by Nanoparticle Positron Emission Tomography-Computed Tomography," Arteriosclerosis, Thrombosis, and Vascular Biology, Vol. 31, No. 4, 2011, pp. 750-757. doi:10.1161/ATVBAHA.110.221499

[75] C. Reeps, M. Essler, J. Pelisek, S. Seidl, H. H. Eckstein and B. J. Krause, "Increased 18F-Fluorodeoxyglucose Uptake in Abdominal Aortic Aneurysms in Positron Emission/Computed Tomography Is Associated with Inflammation, Aortic Wall Instability and Acute Symptoms," Journal of Vascular Surgery, Vol. 48, No. 2, 2008, pp. 417-423. doi:10.1016/j.jvs.2008.03.059

[76] J. S. Lindholt, S. Vammen, H. Fasting, E. W. Henneberg and L. Heickendorff, "The Plasma Level of Matrix Metalloproteinase 9 May Predict the Natural History of Small Abdominal Aortic Aneurysms. A Preliminary Study," European Journal of Vascular and Endovascular Surgery, Vol. 20, No. 3, 2000, pp. 281-285. doi:10.1053/ejvs.2000.1151

[77] M. Truijers, H. A. Kurvers, S. J. Bredie, W. J. Oyen and J. D. Blankensteijn, "In Vivo Imaging of Abdominal Aortic Aneurysms: Increased FDG Uptake Suggests Inflammation in the Aneurysm Wall," Journal of Endovascular Therapy, Vol. 15, No. 4, 2008, pp. 462-467. doi:10.1583/08-2447.1

[78] C. W. Kotze, L. J. Menezes, R. Endozo, A. M. Groves, P. J. Ell and S. W. Yusuf, "Increased Metabolic Activity in Abdominal Aortic Aneurysm Detected by 18F-Fluorodeoxyglucose (18F-FDG) Positron Emission Tomography/ Computed Tomography (PET/CT)," European Journal of Vascular and Endovascular Surgery, Vol. 38, No. 1, 2009, pp. 93-99. doi:10.1016/j.ejvs.2008.12.016

[79] C. W. Kotze, A. M. Groves, L. J. Menezes, R. Harvey, R. Endozo, I. A. Kayani, P. J. Ell and S. W. Yusuf, "What Is the Relationship between (18)F-FDG Aortic Aneurysm Uptake on PET/CT and Future Growth Rate?" European Journal of Nuclear Medicine and Molecular Imaging, Vol. 38, No. 8, 2011, pp. 1493-1499. doi:10.1007/s00259-011-1799-8

[80] E. S. Di Martino, A. Bohra, J. P. Vande Geest, N. Gupta, M. S. Makaroun and D. A. Vorp, "Biomechanical Properties of Ruptured Versus Electively Repaired Abdominal
Aortic Aneurysm Wall Tissue," Journal of Vascular Surgery, Vol. 43, No. 3, 2006, pp. 570-576. doi:10.1016/i.jvs.2005.10.072

[81] J. Ishikawa, K. Kario, Y. Matsui, S. Shibasaki, M. Morinari, R. Kaneda, S. Hoshide, K. Eguchi, Y. Hojo and K. Shimada, "Collagen Metabolism in Extracellular Matrix May be Involved in Arterial Stiffness in Older Hypertensive Patients with Left Ventricular Hypertrophy," Hypertension Research, Vol. 28, No. 12, 2005, pp. 995-1001.

[82] S. Meaume, A. Benetos, O. F. Henry, A. Rudnichi and M. E. Safar, "Aortic Pulse Wave Velocity Predicts Cardiovascular Mortality in Subjects $>70$ Years of Age," Arteriosclerosis, Thrombosis, and Vascular Biology, Vol. 21, No. 12, 2001, pp. 2046-2050. doi: $10.1161 /$ hq1201.100226

[83] J. M. Boese, M. Bock, S. O. Schoenberg and L. R. Schad, "Estimation of Aortic Compliance Using Magnetic Resonance Pulse Wave Velocity Measurement," Physics in Medicine and Biology, Vol. 45, No. 6, 2000, pp. 17031713. doi:10.1088/0031-9155/45/6/320

[84] R. Krug, J. M. Boese and L. R. Schad, "Determination of Aortic Compliance from Magnetic Resonance Images Using an Automatic Active Contour Model," Physics in Medicine and Biology, Vol. 48, No. 15, 2003, pp. 23912404. doi:10.1088/0031-9155/48/15/310

[85] Sakamoto, E. Sueyoshi and M. Uetani, "MR Imaging of the Aorta," Radiologic Clinics of North America, Vol. 45, No. 3, 2007, pp. 485-497. doi:10.1016/j.rcl.2007.04.007

[86] D. P. Naidich, W. R. Webb, N. L. Muller, I .Vlahos and G. A. Krinsky, "Computed Tomography and Magnetic Resonance of the Thorax," 4th Edition, Lippincott Williams \& Wilkins, Philadelphia, 2007, pp. 87-216.

[87] Z. Touat, V. Ollivier, J. Dai, M. G. Huisse, A. Bezeaud, U. Sebbag, T. Palombi, P. Rossignol, O. Meilhac, M. C. Guillin and J. B. Michel, "Renewal of Mural Thrombus Releases Plasma Markers and Is Involved in Aortic Abdominal Aneurysm Evolution," The American Journal of Pathology, Vol. 168, No. 3, 2006, pp. 1022-1030. doi:10.2353/ajpath.2006.050868

[88] L. Sarda-Mantel, M. Coutard, F. Rouzet, O. Raguin, J. M. Vrigneaud, F. Hervatin, G. Martet, Z. Touat, P. Merlet, G. D. Le and J. B. Michel, "99mTc-Annexin-V Functional Imaging of Luminal Thrombus Activity in Abdominal Aortic Aneurysms," Arteriosclerosis, Thrombosis, and Vascular Biology, Vol. 26, No. 9, 2006, pp. 2153-2159. doi:10.1161/01.ATV.0000237605.25666.13

[89] R. A. Trivedi, C. Mallawarachi, J. M. King-Im, M. J. Graves, J. Horsley, M. J. Goddard, A. Brown, L. Wang, P. J. Kirkpatrick, J. Brown and J. H. Gillard, "Identifying Inflamed Carotid Plaques Using in vivo USPIO-Enhanced MR Imaging to Label Plaque Macrophages," Arteriosclerosis, Thrombosis, and Vascular Biology, Vol. 26, No. 7, 2006, pp. 1601-1606. doi:10.1161/01.ATV.0000222920.59760.df

[90] G. H. Turner, A. R. Olzinski, R. E. Bernard, K. Aravindhan, R. J. Boyle, M. J. Newman, S. D. Gardner, R. N. Willette, P. J. Gough and B. M. Jucker, “Assessment of 
Macrophage Infiltration in a Murine Model of Abdominal Aortic Aneurysm," Journal of Magnetic Resonance Imaging, Vol. 30, No. 2, 2009, pp. 455-460. doi:10.1002/jmri.21843

[91] M. Richards, S. I. Semple, T. J. Macgillivray, C. Gray, J. P. Langrish, M. Williams, M. Dweck, W. Wallace, G.
McKillop, R. T. Chalmers, O. J. Garden and D. E. Newby, "Abdominal Aortic Aneurysm Growth Predicted by Uptake of Ultrasmall Superparamagnetic Particles of Iron Oxide: A Pilot Study," Circulation: Cardiovascular Imaging, Vol. 4, No. 3, 2011, pp. 274-281. 